\title{
Оцінка структурного і функціонального стану підшлункової залози у різних групах паціентів з хронічним біліарним панкреатитом
}

\begin{abstract}
Мета роботи: оцінка структурного і функціонального стану підшлункової залози у різних групах пацієнтів з хронічним біліарним панкреатитом терапевтичного профілю та після хірургічних втручань.

Матеріали і методи. Досліджено 115 хворих на хронічний біліарний панкреатит. Для визначення впливу етіологічного біліарного чинника вони були поділені на 4 групи. До 1 групи (26 хворих) належали хворі на ХП в поєднанні з функціональними розладами (ФР) біліарної системи. 2 групу (30 хворих) складали хворі на ХП в поєднанні з некам'яним хронічним холециститом (HXX). До 3 групи (34 хворих ) належали хворі на ХП після перенесеної лапаротомічної ХЕ (ЛТХЕ). У 4 групу (25 хворих) входили хворі на ХП після перенесеної малоінвазивної XЕ (MIXE).

Вік хворих - від 30 до 71 року. Пацієнти були зіставними за віком, статтю і тривалістю захворювання, що становила (10,0 1,5$)$ років. Зовнішньосекреторну функцію підшлункової залози оцінювали за допомогою фекальної $\alpha$-еластази, яку визначали методом імуноферментного аналізу, і показника копрограми, вираженого у балах. Оцінку стану та структури підшлункової залози проводили методом еластографії хвилі зсуву за допомогою скануючого УЗ-апарата Ultima PA.

Результати досліджень та їх обговорення. Показники зовнішньосекреторної функції підшлункової залози погіршувались із поглибленням патологічного процесу в гепатобіліарній системі. Спостерігалась виражена екскреторна недостатність за обома досліджуваними параметрами. Отримані результати довели, що найбільше порушеною структура підшлункової залози була у групі хворих на ХП+ЛТХЕ, а найнижчі показники жорсткості спостерігались у групі ХП+МІХЕ. Було встановлено наступний рейтинг впливовості етіологічного біліарного чинника на структурний і функціональний стан підшлункової залози у бік зменшення рівня жорсткості і покращення її екскреторної функції: лапаротомічна холецистектомія > некалькульозний холецистит = функціональні розлади гепатобіліарної системи > малоінвазивна холецистектомія.
\end{abstract}

Ключові слова: хронічний панкреатит; біліарний генез; холецистектомія; підшлункова залоза; структурний стан.

Постановка проблеми і аналіз останніх досліджень та публікацій. Захворювання органів травлення невпинно зростають у всьому світі, що пов'язано із збільшеним вживанням алкоголю, надмірним споживанням гострої та жирної їжі, курінням, психоемоційними факторами, зниженням соціального рівня населення, супутньою патологією [5, 8]. За останні роки поширеність захворювань органів травлення серед населення України збільшилась на 24,7 \%, захворюваність на 8,7 \%, смертність - на 14,0 \% [4, 7, 11$]$.

Хронічний панкреатит (ХП) є однією з найпоширеніших і найактуальніших проблем у сучасній гастроентерології через труднощі ранньої діагностики та низьку ефективність лікування $[1,9$, 12]. Рання діагностика захворювання залишається утрудненою, особливо при легких та стертих формах ХП, при яких метаболічні та патоморфологічні порушення в тканині залози компенсовані, клінічні симптоми захворювання стерті або практично не проявляються $[14,15]$. ХП є хронічним, тривалістю понад 6 міс., прогресивним захворюванням, що характеризується запально-дистрофічними i, меншою мірою, некротичними змінами в підшлунковій залозі (ПЗ); порушенням прохідності її проток, повторними загостреннями і по- ступовим заміщенням паренхіми органа сполучною тканиною з розвитком його екзо- й ендокринної недостатності [18].

До числа найпоширеніших причин розвитку ХП належать ураження печінки та жовчовивідних шляхів (ЖВШ). За різними даними світової наукової літератури, в 35-60 \% випадків патологія ЖВШ є фактором, який призводить до виникнення ХП $[6,10]$. Показники поширеності захворювань ЖВШ коливаються від 26,6 до 45,5 випадків на 100000 населення. Близько третини населення усієї планети страждає на біліарну патологію. Патологія біліарної системи характеризується значною поширеністю, різноманітністю клінічних проявів, розвитком ускладнень. Тому своєчасна кваліфікована діагностика, раціональне лікування та профілактика мають велике значення і можуть запобігти розвитку низки ускладнень. Протягом останніх десятиліть спостерігається невпинний ріст захворювань біліарно-панкреатодуоденальної зони.

Жовчнокам'яна хвороба (ЖКХ) - захворювання гепатобіліарної системи, зумовлене порушенням метаболізму холестерину i/або білірубіну в поєднанні з іншими чинниками, що призводять до утворення каменів у жовчному міхурі, та є од- 
нією з найчастіших причин виникнення хронічного біліарного панкреатиту (ХБП), який впродовж останніх років має тенденцію до зростання. Захворюваність на ЖКХ з кожним десятиріччям збільшується у 2 рази. Також статистичні дані свідчать про омолодження вказаної патології. В Україні поширеність ЖКХ становить 5-12 \%, тоді як у країнах Північної Америки та Європи, де населення вживає переважно їжу, багату на ХС, цей показник становить $30 \%[2,13]$.

ЖКХ часто поєднується 3 іншими захворюваннями. Багато дослідників та науковців стверджують, що ЖКХ не є самостійною нозологічною одиницею, а завжди поєднується із хронічним холециститом (XX), який вважають початковою (фізико-хімічною) стадією [16]. XX - хронічне запальне захворювання стінки жовчного міхура, що супроводжується порушенням його моторної функції і всмоктувальної здатності, зміною структури і властивостей жовчі (дисхолія) з частим залученням до процесу жовчних судин (ангіохоліт) і проток (холангіт).

Серед біліарної патології, що призводить до виникнення ХП, виділяють також дискінезії жовчовивідних шляхів, які проявляються порушенням моторно-евакуаторної функції ЖМ та жовчних шляхів. Дискінезії можуть бути як самостійним захворюванням, так і супроводжувати ЖКХ, холецистит. Частка дискінезій у системі захворювань жовчовивідної системи складає 12-25\%.

Серед причин розвитку виділяють аліментарні (харчова алергія, нерегулярне харчування, вживання низькокалорійної їжі, смаженої, жирної в поєднанні з малорухомим способом життя), порушення нервової регуляції роботи ЖМ, зміни рівня гормонів ШКТ і ендокринних залоз (клімакс, недостатність надниркових залоз, одиночні кісти і полікістоз яєчників, гіпотиреоз, тиреотоксикоз, ожиріння, цукровий діабет, при виразковій хворобі, гастриті, дуоденіті, захворюваннях хребта. Запальний процес у слизовій оболонці дванадцятипалої кишки призводить до порушення секреції гормону холецистокініну-панкреозиміну (ХК-ПЗ), який відіграє головну роль у регуляції моторики.

Дискінезії поділяють на гіпокінетичні (атонічні) - при переважанні тонусу парасимпатичної нервової системи, та гіперкінетичні (спастичні) - при переважанні тонусу симпатичної нервової системи. При першому типі виявляють збільшення ЖМ, сповільнення його скоротливої функції, застій жовчі. При другому типі спостерігаються протилежні зміни: пришвидшене скорочення ЖМ, зменшення кількості жовчі у ньому, виділення жовчі невеликими порціями.
При обох типах дискінезій у результаті неузгодженої роботи ЖМ і сфінктерів жовчних проток порушується надходження жовчі в просвіт дванадцятипалої кишки, що призводить до виникнення ХБП та інших розладів травлення.

За статистикою, в основному хворіють жінки, в 10 разів частіше, ніж чоловіки. Часто хворіють вагітні, оскільки у них знижується тонус матки, кишечника, жовчних шляхів.

Перебіг ЖКХ у багатьох випадках супроводжується супутніми захворюваннями органів травлення, а саме гепатопанкреатобіліарної зони. Протягом останніх років ЖКХ має тенденцію до зростання, як у країнах Європи, так і в Україні. Відповідно, збільшується й кількість холецистектомій (XЕ). Щорічно у світі виконується 2,5 млн $\mathrm{XE}$, тобто по частоті виконання це оперативне втручання поступається тільки апендектомії [19]. Незважаючи на те, що XE є основним етіопатогенетичним методом лікування, але далеко не завжди вирішує проблему і навіть може спровокувати загострення чи прогресування супутньої патології. Серед органів гепатопанкреатодуоденальної зони видалення ЖМ найчастіше відображається на функціонуванні ПЗ. ХП розвивається більше ніж у половини пацієнтів, що перенесли оперативне втручання з приводу ЖКХ [3, 17].

За даними В. А. Зоріної та інших авторів, при обстеженні хворих після ХЕ у 85 \% виявлено підвищений вміст в крові $\alpha_{1}$-антитрипсину, причому в 34,7 \% випадків показники переважають норму більш ніж удвічі. Своєчасна і технічно грамотно виконана операція, особливо на початкових стадіях ЖКХ, не відображається на функціональному стані ПЗ. У випадку повного відновлення прохідності жовчних і панкреатичних шляхів знижується ступінь вираженості патологічних процесів у ПЗ, настає регенерація панкреатоцитів і підвищується їх активність. Репаративні процеси починаються зі строми і характеризуються зворотним розвитком сполучної тканини, переходять на паренхіму, що сприяє відновленню функціональної активності залози. Швидкість відновлення після операції залежить від варіанту ХЕ (традиційна, лапароскопічна, XЕ через міні-доступ) [3]. Але при тривалому процесі повне відновлення не настає.

Близько третину хворих, що перенесли в анамнезі XE, продовжують турбувати абдомінальний біль та диспепсичні розлади. Їх наявність пов'язана із двома основними чинниками: з порушеним обміном холестерину (етіологічний чинник ЖКХ), та тим, що жовчовиділення проходить у нових анатомо-фізіологічних умовах (за відсутності ЖМ) [15]. 
Мета роботи: оцінка структурного і функціонального стану підшлункової залози у різних групах пацієнтів з хронічним біліарним панкреатитом терапевтичного профілю та після хірургічних втручань.

Матеріали і методи. Досліджено 115 хворих на хронічний біліарний панкреатит. Для визначення впливу етіологічного біліарного чинника вони були поділені на 4 групи. До 1 групи (26 хворих) належали хворі на ХП в поєднанні з функціональними розладами (ФР) біліарної системи. 2 групу (30 хворих) складали хворі на ХП в поєднанні $з$ некам'яним хронічним холециститом (HXX). До 3 групи (34 хворих ) належали хворі на ХП після перенесеної лапаротомічної ХЕ (ЛТХЕ). У 4 групу (25 хворих) входили хворі на ХП після перенесеної малоінвазивної XE (MIXE).

Вік хворих - від 30 до 71 року. Пацієнти були зіставними за віком, статтю і тривалістю захворювання, що становила $(10,0 \pm 1,5)$ років.

Зовнішньосекреторну функцію (ЗСФ) ПЗ оцінювали за допомогою фекальної $\alpha$-еластази, яку визначали методом імуноферментного аналізу, і показника копрограми, вираженого у балах.

Оцінку стану та структури ПЗ проводили методом еластографії хвилі зсуву (ЕХ3) за допомогою скануючого УЗ-апарата Ultima РА (“Радмир” ДП
АТ НДІРІ, Харків, Україна) контактно датчиком конвексного формату на частотах 2-5 МГц на глибині 10-50 мм. При обстеженні ПЗ в ділянках головки, тіла та хвоста проводили по 5 вимірювань.

Результати досліджень та їх обговорення. Показники ЗСФ ПЗ (фекальна $\alpha$-еластаза і показник копрограми) із поглибленням патологічного процесу у гепатобіліарній системі погіршувались (табл. 1).

У пацієнтів групи ХП+ЛТХЕ спостерігалась виражена екскреторна недостатність за обома досліджуваними параметрами, що було достовірно змінено $(p<0,05)$ відповідно до таких показників у інших групах хворих (ХП+НХХ, ХП+ФР і ХП+МІХЕ), де ЗСФ відповідала середньому ступеню тяжкості.

Наступним кроком нашого дослідження було вивчення структурного стану ПЗ (табл. 2). Найвищими показники жорсткості ПЗ виявилися у групі ХП+ЛТХЕ, вони були достовірно вищими відносно таких у групах ХП+НХХ, ХП+ФР та XП+MIXE $(\mathrm{p}<0,05)$. Достовірної різниці між показниками жорсткості груп ХП+НХХ і ХП+ФР не виявлено, проте вони були достовірно вищими порівняно з аналогічними показниками групи XП+MIXE $(p<0,05)$, в якій були виявлені найнижчі показники жорсткості.

Таблиця 1. Порівняльний аналіз показників ЗСФ ПЗ у групах хворих на ХБП за етіологічним чинником

\begin{tabular}{||l|c|c|c|c|c||}
\hline \hline \multirow{2}{*}{ Показник ЗСФ ПЗ } & \multirow{2}{*}{$\begin{array}{c}\text { Група } \\
\text { контролю } \\
(\mathrm{n}=20)\end{array}$} & $\begin{array}{c}\text { ХП+ФР } \\
(\mathrm{n}=25)\end{array}$ & $\begin{array}{c}\text { ХП+НХХ } \\
(\mathrm{n}=30)\end{array}$ & $\begin{array}{c}\text { ХП+ЛТХЕ } \\
(\mathrm{n}=34)\end{array}$ & $\begin{array}{c}\text { ХП+МІХЕ } \\
(\mathrm{n}=26)\end{array}$ \\
\cline { 3 - 6 } & $219,44 \pm 5,74$ & $140,53 \pm 5,53 *$ & $120,86 \pm 3,17 * * ¥$ & $90,26 \pm 2,88 * * * \S \propto$ & $134,44 \pm 4,56 *$ \\
\hline $\begin{array}{l}\text { Фекальна } \\
\alpha \text {-еластаза, мкг/Г }\end{array}$ & 0 & $12,60 \pm 0,96 *$ & $16,30 \pm 0,53 * * ¥$ & $21,03 \pm 0,83 * * * \S \propto$ & $10,07 \pm 0,93 *$ \\
\hline $\begin{array}{l}\text { Сумарно } \\
\text { копрограма, бали }\end{array}$ & & & & \\
\hline
\end{tabular}

Примітки (тут і в таблиці 2): 1. * достовірна відмінність порівняно з групою контролю (р<0,05);

2. ** - достовірна відмінність показників між групою хворих на ХП+ФР та групою ХП+НХХ $(\mathrm{p}<0,05)$;

3. *** - достовірна відмінність показників між групою хворих на ХП+ФР та групою ХП+ЛТХЕ $(\mathrm{p}<0,05)$;

4. $£$ - достовірна відмінність показників між групою хворих на ХП+ФР та групою ХП+МIXЕ $(\mathrm{p}<0,05)$;

5. § - достовірна відмінність показників між групою хворих на ХП+НХХ та групою ХП+ЛТХЕ $(\mathrm{p}<0,05)$;

6. - - достовірна відмінність показників між групою хворих на ХП+ЛТХЕ та групою ХП+МIXЕ $(\mathrm{p}<0,05)$;

7. $¥$ - достовірна відмінність показників між групою хворих на ХП+НXX та групою ХП+MIXE $(\mathrm{p}<0,05)$

Таблиця 2. Порівняльний аналіз показників жорсткості підшлункової залози у групах хворих на хронічний біліарний панкреатит за етіологічним чинником

\begin{tabular}{|c|c|c|c|c|c|}
\hline \multirow{2}{*}{$\begin{array}{c}\text { Показник } \\
\text { EX3 }\end{array}$} & \multirow{2}{*}{$\begin{array}{c}\text { Група } \\
\text { контролю } \\
(\mathrm{n}=20)\end{array}$} & \multicolumn{4}{|c|}{ Група порівняння } \\
\hline & & $\begin{array}{c}X \Pi+\Phi P \\
(n=25)\end{array}$ & $\begin{array}{c}\mathrm{X \Pi +HXX} \\
(\mathrm{n}=30)\end{array}$ & $\begin{array}{c}\text { ХП+ЛТХЕ } \\
(n=34)\end{array}$ & $\begin{array}{c}\text { XП+MIXE } \\
(n=26)\end{array}$ \\
\hline ПЗ, кПа & $4,67 \pm 0,32$ & $6,52 \pm 0,25 *$ & $7,36 \pm 0,21^{* *} ¥$ & $7,89 \pm 0,13^{* * *} \S a$ & $6,24 \pm 0,17 *$ \\
\hline
\end{tabular}


Отримані результати довели, що найбільш порушеною структура ПЗ була у групі пацієнтів ХП+ЛТХЕ, а найнижчі показники жорсткості спостерігались у групі ХП+МIXЕ.

Таким чином, було встановлено наступний рейтинг впливу етіологічного біліарного чинника на структурний і функціональний стан підшлункової залози у бік зменшення рівня жорсткості і покращення її екскреторної функції: лапаротомічна холецистектомія > некалькульозний холецистит = функціональні розлади гепатобіліарної системи > малоінвазивна холецистектомія.

\section{СПИСОК ЛІТЕРАТУРИ}

1. Бабінець Л. С. Патогенетичні аспекти хронічного панкреатиту біліарного генезу після холецистектомії / Л. С. Бабінець, Н. В. Назарчук // Вестник клуба панкреатологов. 2014. - № 3 (24). - С. 4-8.

2. Зв'ягинцева Т. Д. ПХЕС: дисфункция сфинктера Одди / Т. Д. Зв’ягинцева, И. И. Шаргород // Ліки України. - 2012. № 2 (148). - С. 100-106.

3. Место ингибиторов протонной помпы в лечении хронического панкреатита. Обзор и собственное наблюдение / Н.Б.Губергриц, Н. В. Беляева, А. Е. Клочков [и др.] // Сучасна гастроентерологія. - 2018. - № 4. - С. 85-94.

4. Уніфікований клінічний протокол первинної, вторинної (спеціалізованої) медичної допомоги та медичної реабілітації. Хронічний панкреатит : наказ МОЗ України від 10.09.2014 № 638. - К., 2014. - 34 с.

5. Новости Европейской панкреатологии (по материалам 50-й встречи Европейского Клуба Панкреатологов) / Н. Б. Губергриц, Н. В. Беляева, Г. М. Лукашевич [и др.] // Вестник клуба панкреатологов. - 2019. - № 4 (41). - С. 4-15. 6. Селезнева Е. Я. Коррекция функционального билиарного расстройства - реальная профилактика холелитиаза / Е. Я. Селезнева // Фарматека. - 2019. - № 2. - С. 93-96.

7. Соловьева Г. А. Диагноз хронического панкреатита: истинные критерии / Г. А. Соловьева // Мистецтво лікування. - 2015. - № 5-6. - С. 54-56.

8. Соломенцева Т. А. Рекомендації Об’єднаної європейської гастроентерологічної асоціації $з$ діагностики та лікування хронічного панкреатиту / Т. А. Соломенцева // Сучасна гастроентерологія. - 2018. - № 3. - С. 78-93.

9. Степанов Ю. М. Хронічний панкреатит: біліарний механізм, чинники та перебіг / Ю. М. Степанов, Н. Г. Заіченко // Запорожский медицинский журнал. - 2012. - № 1 (70). - С. 46-50. 10. Холецистэктомия и сфинктер Одди: как достигнуть консенсуса? / Н. Б. Губергриц, Г. М. Лукашевич, О. А. Голубова,
Висновок. Доведено достовірно меншу глибину пошкодження структури підшлункової залози та її функції у пацієнтів після малоінвазивної холецистектомії, порівняно з такими після лапаротомічної холецистектомії, що вказує на доцільність проведення оперативного втручання на ранніх етапах розвитку жовчнокам’яної хвороби.

Перспективи подальших досліджень. Плануємо провести аналіз стану структури підшлункової залози та ії функції при хронічному панкреатиті після перенесеного гострого панкреатиту в анамнезі.

П. Г. Фоменко // Сучасна гастроентерологія. - 2013. - № 1. C. 55-65.

11. Христич Т. Н. Етіологічні фактори, що формують хронічний панкреатит / Т. Н. Христич, Д. А. Гонцарюк // Здобутки клінічної і експериментальної медицини. - 2018. - № 3. - С. 20-28.

12. Machicadoetal J. D. A population-based evaluation of the natural history of chronic pancreatitis / J. D. Machicadoetal // Pancreatology. - 2018. - Vol. 18, No. 1. - P. 39-45.

13. Byelyayeva N. V. Treatment of chronic biliary pancreatitis in patients with obesity / N. V. Byelyayeva // Pancreatology. - 2016. - Vol. 16, No. 1. - P. S6-S4.

14. Rodriguesetal E. Clube Portugues do pancreas recommendations for chronic pancreatitis: Etiology, natural history, and diagnosis (Part 1) / E. Rodriguesetal // Portugese Journal of Gastroenterology. - 2019. - No. 26. - P. 346-355.

15. Di Magno E. P. Chronic pancreatitis: land mark papers, management decisions, and future / E. P. Di Magno, M. J. Di Magno // Pancreas. - 2016. - Vol. 45, No. 5. - P. 641-650.

16. Imm N. Gall stones and cholecystitis / N. Imm. [Electronic resource]. - 2016. Access mode : https://patient.info/doctor/ gallstones-and-cholecystitis.

17. Improvement of the complex medical treatment for the patients with chronic biliary pancreatitis / L. Babinets, K. Kytsai, Yu. Kotsaba [et al.] // Wiedomosti Lekarskie. - 2017. - No. 2 (1). - P. 213-216.

18. Recommendations from the United European Gastroenterology evidence-based guidelines for the diagnosis and therapy of chronic pancreatitis / J. E. Dominguez-Munoz, A. M. Drewes, B. Lindkvist [et al.] // Pancreatology. - 2018. Vol. 18, No. 8. - P. 847-854.

19. Turumin J. L. Postcholecystectomy syndrome, or condition after cholecystectomy (gallblader removal) [Electronic resource] / J. L. Turumin. - Access mode : http://www.drturumin.com.

\section{REFERENCES}

1. Babinets, L.S., \& Nazarchuk, N.V. (2014). Patohenetychni aspekty khronichnoho pankreatytu biliarnoho henezu pislia kholetsystektomii [Pathogenetic aspects of chronic pancreatitis of biliary genesis after cholecystectomy]. Vestnyk kluba pankreatologov - Journal of the Pancreatology Club, 3 (24), 4-8 [in Ukrainian].

2. Zvyagintseva, T.D., \& Shargorod, I.I. (2012). PKhES: disfunktsiya sfinktera Oddi [PCAC]. Liky Ukrainy - Medicines of Ukraine, 2 (148), 100-106 [in Russian].

3. Gubergrits, N.B., Belyayeva, N.V., Klochkov, A.Ye., Suprun, A.A., \& Fomenko, P.G. (2018). Mesto ingibitorov protonnoy pompy v lechenii khronicheskogo pankreatita. Obzor i sobstvennye nablyudeniya [Place of proton pump inhibitors in the treatment of chronic pancreatitis. Review and own observations]. Suchasna hastroenterolohiia - Modern Gastroenterology, 4, 85-94 [in Ukrainian].

4. Nakaz MOZ Ukrainy vid 10.09.2014 № 638. Unifikovanyi klinichnyy protokol pervynnoi, vtorynnoi (spetsializovanoi) me- 
dychnoi dopomohy ta medychnoi reabilitatsii. Khronichnyi pankreatyt [Order of the MHU No. 638 dated September 10, 2014. Unified clinical protocol of primary, secondary (specialized) medical care and medical rehabilitation. Chronic Pancreatitis]. Kyiv [in Ukrainian].

5. Gubergrits, N.B., Belyayeva, N.V., Lukashevich, G.M., Klochkov, A.Ye., Fomenko, P.G., Yaroshenko, L.A., ..., \& Rakhmetova, V.S. (2019). Novosti Yevropeyskoy pankreatologii (po materialam 50-y vstreche Yevropeyskogo Kluba Pankreatologov) [News of European Pancreatology (based on the materials of the 50th meeting of the European Club of Pancreatologists)]. Vestnik kluba pankreatologov - Bulletin of the Pancreatologists Club, 4 (41), 4-15 [in Russian].

6. Selezneva, Ye.Ya. (2019). Korrektsiya funktsionalnogo biliarnogo rasstroystva - realnaya proffilaktika kholelitiaza [Correction of functional biliary disorder - a real prevention of cholelithiasis]. Farmateka - Farmateca, 2, 93-96 [in Russian].

7. Solovyeva, G.A. (2015). Diagnoz khronicheskogo pankreatita: istinnyye kriterii [The diagnosis of chronic pancreatitis: true criteria]. Mystetstvo likuvannia - The Art of Healing, 5-6, 54-56 [in Russian].

8. Solomentseva, T.A. (2018). Rekomendatsii Obiednanoi yevropeiskoi hastroenterolohichnoi asotsiatsii z diahnostyky ta likuvannia khronichnoho pankreatytu [Recommendations of the United European Gastroenterology Association for the diagnosis and treatment of chronic pancreatitis]. Suchasna hastroenterolohiia Modern Gastroenterology, 3, 78-93 [in Ukrainian].

9. Stepanov, Yu.M., \& Zaichenko, N.H. (2012). Khronichnyi pankreatyt: biliarnyi mekhanizm, chynnyky ta perebih [Chronic pancreatitis: biliary mechanism, factors and course]. Zaporozhskiy medytsynskiy zhurnal - Zaporozhye Medical Journal, 1 (70), 46-50 [in Ukrainian].

10. Gubergrits, N.B., Lukashevich, G.M., Golubova, O.A., \& Fomenko, P.G. (2013). Kholetsistektomiya i sfinkter Oddi: kak dostignut konsensusa? [Cholecystectomy and sphincter of Oddi: how to reach consensus?]. Suchasna hastroenterolohiia - Modern Gastroenterology, 1, 55-65 [in Ukrainian].

11. Khrystych, T.N., \& Hontsariuk, D.A. (2018). Etiolohichni faktory, shcho formuiut khronichnyi pankreatyt [Etiological factors which form the chronical pancreatitis]. Zdobutky klinichnoi $i$ eksperymentalnoi medytsyny - Achievements of Clinical and Experimental Medicine, 3, 20-28 [in Ukrainian].

12. Machicadoetal, J.D. (2018). A population-based evaluation of the natural history of chronic pancreatitis. Pancreatology, 18, 1, 39-45.

13. Byelyayeva, N.V. (2016). Treatment of chronic biliary pancreatitis in patients with obesity. Pancreatology, 16, 1, S6-S4.

14. Rodriguesetal, E. (2019). Clube Portugues do pancreas recommendations for chronic pancreatitis: Etiology, natural history, and diagnosis (Part 1). Portugese Journal of Gastroenterology, 26, 346-355.

15. Di Magno, E.P., \& Di Magno, M.J. (2016). Chronic pancreatitis: land mark papers, management decisions, and future. Pancreas, 45, 5, 641-650.

16. Imm, N. (2016). Gall stones and Cholecystitis. Retrieved from: https://patient.info/doctor/gallstones-and-cholecystitis.

17. Babinets, L., Kytsai, K., Kotsaba, Yu., Halabitska, I., Melnyk, N., Semenova, I., \& Zemlyak, O. (2017). Improvement of the complex medical treatment for the patients with chronic biliary pancreatitis. Wiedomosti Lekarskie, 2 (1), 213-216.

18. Dominguez-Munoz, J.E., Drewes, A.M., Lindkvist, B., Ewald, N., Czakó, L., Rosendahl, J., \& Löhr, J.M. (2018). Recommendations from the United European Gastroenterology evidence-based guidelines for the diagnosis and therapy of chronic pancreatitis. Pancreatology, 18, 8, 847-854.

19. Turumin, J.L. Postcholecystectomy syndrome, or condition after cholecystectomy (gallblader removal). Retrieved from: http://www.drturumin.com.

Отримано 05.11.2019

Електронна адреса для листування: kateryna.kytsai@ukr.net

\author{
L. S. BABINETS, K. YU. KYTSAI, B. O. MIHENKO
}

I. Horbachevsky Ternopil National Medical University

\title{
ASSESSMENT OF THE STRUCTURAL AND FUNCTIONAL STATE OF THE PANCREAS IN DIFFERENT GROUPS OF PATIENTS WITH CHRONIC BILIARY PANCREATITIS
}

The aim of the work: assessment of the structural and functional status of the pancreas in different groups of patients with chronic biliary pancreatitis on conservative management and after surgical intervention.

Materials and Methods. 115 patients with chronic biliary pancreatitis were divided into 4 groups. Group 1 (26 patients) included patients with CP combined with functional disorders (FD) of the biliary system. Group 2 (30 patients) consisted of patients with CP in combination with not-stone chronic cholecystitis (NCC). Group 3 (34 patients) included patients with CP after laparotomy cholecystectomy (LTCE). Group 4 (25 patients) included patients with CP after minimally invasive cholecystectomy (MICE).

Age of patients - from 30 to 71 years. Patients were comparable in age, sex, and disease duration to (10.0 \pm 1.5$)$ years. External secretory function of the pancreas was evaluated using fecal $\alpha$-elastase, which was determined by the method of enzyme-linked immunosorbent assay, and the index of coprogram expressed in points. Evaluation of the condition and structure of the pancreas was performed by the elastography of the shear wave with the scanning ultrasound equipment Ultima PA.

Results and Discussion. Indicators of the extracellular function of the pancreas worsened with the deepening of the pathological process in the hepatobiliary system. There was a marked excretory insufficiency in both studied parameters.

The results proved that the most damaged structure of the pancreas was in the CP+LTCE group of patients, and the lowest indicators of stiffness were observed in the CP+MICE group.

The following rating of influence of etiologic biliary factor on the structural and functional state of the pancreas towards reducing the level of rigidity and improving its excretory function was established: laparotomic cholecystectomy $>$ non-calculous cholecystitis $=$ functional disorders of hepatocellular system.

Key words: chronic pancreatitis; biliary genesis; cholecystectomy; pancreas; structural condition. 


\author{
Л. С. БАБИНЕЦ, Е. Е. КИЦАЙ, Б. О. МИГЕНЬКО
}

Тернопольский национальный медицинский университет имени И. Я. Горбачевского Моз Украины

\title{
ОЦЕНКА СТРУКТУРНОГО И ФУНКЦИОНАЛЬНОГО СОСТОЯНИЯ ПОДЖЕЛУДОЧНОЙ ЖЕЛЕЗЫ В РАЗНЫХ ГРУППАХ ПАЦИЕНТОВ С ХРОНИЧЕСКИМ БИЛИАРНЫМ ПАНКРЕАТИТОМ
}

\begin{abstract}
Цель работы: оценка структурного и функционального состояния поджелудочной железы в разных группах пациентов с хроническим билиарным панкреатитом терапевтического профиля и после хирургических вмешательств.

Материалы и методы. Исследовано 115 больных хроническим билиарным панкреатитом, которые были поделены на 4 группы. В 1 группу (26 больных) вошли больные ХП в сочетании с функциональными расстройствами (ФР) билиарной системы. 2 группу (30 больных) составили больные ХП в сочетании с некаменным хроническим холециститом (НХХ). В 3 группу (34 больных) вошли больные ХП после перенесенной лапаротомической ХЭ (ЛТХЭ). В 4 группу (25 больных) входили больные ХП после перенесенной малоинвазивной ХЭ (МИХЭ).

Возраст больных - от 30 до 71 года. Пациенты были сопоставимы по возрасту, полу и продолжительности заболевания, которая составляла - $(10,0 \pm 1,5)$ лет. Внешнесекреторную функцию поджелудочной железы оценивали с помощью фекальной $\alpha$-эластазы, которую определяли методом иммуноферментного анализа и показателя копрограммы, выраженного в баллах. Оценку состояния и структуры поджелудочной железы проводили методом эластографии волны сдвига с помощью сканирующего УЗ-аппарата Ultima PA.

Результаты исследований и их обсуждение. Показатели внешнесекреторной функции поджелудочной железы ухудшались с углублением патологического процесса в гепатобилиарной системе. Наблюдалась выраженная экскреторная недостаточность по обоим исследуемыми параметрам.

Полученные результаты показали, что наиболее нарушенной структура поджелудочной железы была в группе пациентов ХП+ЛТХЭ, а самые низкие показатели жесткости наблюдались в группе ХП+МИХЭ.

Был установлен следующий рейтинг влиятельности этиологического билиарного фактора на структурное и функциональное состояние поджелудочной железы в сторону уменьшения жесткости и улучшения ее экскреторной функции: лапаротомическая холецистэктомия > некалькулезный холецистит = функциональные расстройства пищеварительной системы $>$ малоинвазивная холецистэктомия.
\end{abstract}

Ключевые слова: хронический панкреатит; билиарный генез; холецистэктомия; поджелудочная железа; структурное состояние. 